\title{
UPAYA PENINGKATAN PRESTASI BELAJAR BAHASA INDONESIA MELALUI METODE COOPERATIVE INTEGRATED READING AND COMPOSITION (CIRC) UNTUK SISWA SMAN 9 KOTA JAMBI
}

\author{
A. SYAHRIL \\ SMA Negeri 9 Kota Jambi, Provinsi Jambi \\ Email : a.syhari1019@gmail.com
}

\begin{abstract}
ABSTRAK
Penelitian ini bertujuan untuk meningkatkan prestasi hasil belajar siswa melalui metode struktural análisis pada mata pelajaran bahasa indonesia untuk kelas X IPS 1 SMA Negeri 9 Kota Jambi Provinsi Jambi tahun pelajaran 2019/2020. Penelitian ini merupakan penelitian tindakan kelas (PTK). Subjek dalam penelitian yaitu siswa kelas X IPS 1 SMA Negeri 9 Kota Jambi tahun ajaran 2019/2020 berjumlah 36 siswa. Prosedur penelitian ini dilakukan melalui empat tahapan yaitu: (1) perencanaan, (2) pelaksanaan, (3) pengamatan dan (4) refleksi. Penelitian ini dilaksanakan melalui 2 (dua) siklus terdiri dari siklus I dan siklus II. Hasil penelitian ini menunjukkan bahwa bahwa penerapan metode CIRC dapat meningkatkan prestasi belajar Bahasa Indonesia pada siswa kelas X IPS 1 SMA Negeri 9 Kota Jambi tahun ajaran 2019/2020. Dari hasil analisis siklus I diperoleh nilai rata-rata 68.05 dengan persentase ketuntasan mencapai 35\%, hal ini menunjukan bahwa siswa belum sepenuhnya mencapai ketuntasan belajar. Pada siklus II, ada peningkatan, untuk siklus II dengan nilai rata-rata 75,95 atau sudah termasuk kriteria sangat baik dengan persentase ketuntasan mencapai $80 \%$. Hal ini menunjukan bahwa adanya peningkatan nilai rata-rata dan persentase ketuntasan belajar siswa pada siklus II, karena 2 kriteria ini sudah memenuhi kriteria ketuntasan maka penelitian dicukupkan di siklus II.
\end{abstract}

Kata Kunci: prestasi belajar, struktural analisis, bahasa indonesia.

\section{PENDAHULUAN}

Bahasa merupakan komponen terpenting dalam kehidupan manusia, manusia tidak akan bisa melanjutkan kelangsungan hidup mereka dengan baik dan teratur tanpa adanya bahasa. Mereka tidak bisa berinteraksi dengan mudah dan baik jika mereka tidak menguasai bahasa antara satu sama lain. Peran bahasa Indonesia dalam keberhasilan pelaksanaan pendidikan sangatlah penting, bahkan seluruh proses pendidikan amat sangat terkait dengan penggunaan media berbahasa, baik secara lisan maupun tulisan (Nai, 2017).

Ciri siswa terampil berbahasa yakni apabila ia terampil menyimak, berbicara, menulis dan membaca. Keterampilan tersebut tidak datang sendirinya, tetapi membutuhkan suatu proses pembelajaran yang tepat, Untuk itu, diperlukan suatu proses pembelajaran yang mendukung upaya peningkatan kemampuan dan keterampilan berbahasa siswa, dengan kata lain dalam proses pembelajaran siswa harus dilibatkan secara aktif, sehingga dapat mengasah ke empat kriteria kemampuan berbahasa tersebut (Wardani, dkk, 2013).

Dalam dunia pendidikan, terdapat berbagai macam tujuan yang ingin dicapai oleh para guru sekaligus bagi para siswa. Salah satu dari tujuan tersebut adalah tercapainya prestasi belajar siswa. Tidak dapat dipungkiri bahwa sejauh ini prestasi belajar merupakan suatu patokan atau acuan bagi para guru untuk mengetahui tingkat pemahaman bagi para siswa. Bentuk prestasi belajar yang lebih sering dikenali adalah berupa nilai angka. Secara umum, nilai angka diperoleh dari nilai tes atau nilai ujian seorang siswa berdasarkan skor jawaban tes yang benar (Sari, dkk, 2017). Rendahnya prestasi belajar siswa pada beberapa mata pelajaran di sekolah, merupakan masalah yang sering dialami di sekolah, berbagai faktor dapat menjadi pemicu atau penyebab mengapa prestasi belajar siswa menjadi rendah seperti motivasi belajar, lingkungan sekolah, minat siswa, faktor guru, serta metode belajar di sekolah. Ada banyak mata pelajaran yang diajarkandi sekolah, mulai dari mata pelajaran wajib hingga mata pelajaran tambahan, seperti yang sering disebut dengan muatan lokal. Mata pelajaran wajib merupakan 
mata pelajaran yang khusus ditempuh oleh siswa untuk lebih fokus dan sebagai mata pelajaran yang akan diujikan pada saat Ujian Nasional di akhir studi, salah satunya adalah Bahasa Indonesia (Susanto, 2016). Prestasi belajar pada hakekatnya merupakan pencerminan dari usaha belajar. Semakin baik usaha belajar seseorang siswa, semakin baik pula prestasi belajar yang diperolehnya. Pencapaian prestasi belajar siswa dipengaruhi berbagai faktor baik internal maupun eksternal (Inayah, 2013).

Adapun Model pembelajaran merupakan perencanaan atau suatu pola yang digunakan sebagai pedoman dalam merencanakan pembelajaran di kelas yang mengacu pada pendekatan pembelajaran yang akan digunakan, termasuk didalamnya tujuan-tujuan pengajaran, tahaptahap dalam kegiatan pembelajaran, lingkungan pembelajaran dan pengelolaan kelas. Penerapan model pembelajaran yang tepat, merupakan salah satu strategi dalam pembelajaran untuk meningkatkan kemampuan akademik siswa. Pendapat yang di kemukakan $\mathrm{Nu}$ Asiah (2014) mengatakan bahwa: Model pembelajaran merupakan strategi yang digunakan oleh guru untuk meningkatkan motivasi belajar, sikap belajar dikalangan siswa, mampu berpikir kritis, memiliki keterampilan sosial, dan pencapaian hasil pembelajaran yang lebih optimal. Sehingga tujuan-tujuan seperti inilah yang sangat diharapkan dalam tercapainya keberhasilan proses pembelajaran, karena mengingat masih ada beberapa pendidik yang belum memaksimalkan proses pembelajaran dengan menggunakan model pembelajaran yang tepat.

Sejalan dengan berkembangnya penelitian di bidang pendidikan maka ditemukan model-model pembelajaran baru yang dapat meningkatkan interaksi siswa dalam proses belajar mengajar, yang dikenal dengan model pembelajaran kooperatif yang merupakan aktivitas pelaksanaan pembelajaran dalam kelompok, yang saling berinteraksi satu sama lain, dimana pembelajaran adalah bergantung kepada interaksi antara kelompok, setiap siswa bertanggung jawab terhadap proses pembelajaran di kelas dan juga di kelompoknya (Nurjaya, 2012). Manfaat penerapan belajar kooperatif adalah dapat mengurangi kesenjangan pendidikan khususnya dalam wujud input pada level individual. Di samping itu, belajar kooperatif dapat mengembangkan solidaritas sosial di kalangan siswa. Dengan belajar kooperatif, diharapkan kelak akan muncul generasi baru yang memiliki prestasi akademik yang cemerlang dan memiliki solidaritas social yang kuat (Muthoharoh, 2017).

Berdasarkan observasi yang dilakukan terhadap siswa di kelas X IPS 1 SMA Negeri 9 Kota Jambi, ditemukan bahwa dalam pembelajaran Bahasa Indonesia siswa terlihat tidak begitu aktif, karena guru masih menggunakan metode pembelajaran yang berpusat pada guru, yaitu metode pembelajaran yang dominan menerapkan ceramah. Guru lebih aktif sedangkan siswa lebih pasif menerima pembelajaran. Dengan kata lain, suasana belajar Bahasa Indonesia siswa kelas X IPS 1 SMA Negeri 9 Kota Jambi terkesan kaku sehingga mengakibatkan proses belajar mengajar tidak berjalan secara optimal.

Berdasarkan hasil pengamatan dan analisis serta refleksi peneliti dan disadarkan dengan hasil observasi yang dilakukan, maka dalam penelitian ini diajukan metode pembelajaran Cooperative Integrated Reading and Composition (CIRC) sebagai alternatif metode pembelajaran yang diharapkan dapat membantu siswa terampil berbahasa serta mengatasi kepasifan siswa selama mengikuti pembelajaran Bahasa Indonesia. Model CIRC adalah pembelajaran kooperatif yang terintegrasi secara menyeluruh kemudian mengomposisikan menjadi bagian-bagian yang penting. Model pembelajaran tipe CIRC lebih menekankan pada aktifitas membaca dan menulis serta seni berbahasa pada tingkat yang lebih tinggi. Model pembelajaran CIRC memiliki komponen-komponen yang dapat membuat kegiatan belajar mengajar menjadi lebih efektif dan kreatif, karena siswa bersama dengan kelompok dapat mengembangkan dan bertukar pengetahuannya untuk mempelajari suatu materi yang ditugaskan oleh guru dan juga terdapat kegiatan pokok pada pembelajaran CIRC dalam menyelesaikan kegiatan pemecahan masalah sehingga melatih siswa untuk berpikir kritis (Ekawati, dkk, 2015).

Dikembangkan oleh Stavens, dkk. Metode CIRC ini dirancang untuk mengakomodasi level kemampuan siswa yang beragam, baik melalui pengelompokan heterogen (heterogeneous 
grouping) maupun pengelompokan homogeny (homogeneous grouping). Dalam CIRC, siswa ditempatkan dalam kelompok-kelompok kecil, baik homogen maupun heterogen. Pertamatama mereka mengikuti serangkaian instruksi guru tentang keterampilan membaca dan menulis, kemudian praktek, lalu penilaian dan kuis. Setiap kelompok tidak bisa mengikuti kuis hingga anggota-anggota didalamnya benar-benar menyatakan bahwa mereka benar-benar siap (Huda, 2015: 126). Dalam penjelasan yang lain ditegaskan bahwa Model pembelajaran cooperative integrated reading and composition (CIRC)merupakan salah satu model kooperatif yang ekstensifditerapkan dalampembelajaran membaca, menulis, dan seni berbahasa dilaksanakandengan cara membentuk kelompok bertujuan agar siswa mampu bekerjasama dengan teman satu kelompoknya untuk menemukan suatu ide pokok suatu materi pembelajaran (Fitriyani, dkk, 2020).

Dalam pembelajaran $C I R C$ atau pembelajaran terpadu setiap siswa bertanggung jawab terhadap tugas kelompok. Setiap anggota kelompok saling mengeluarkan ide-ide untuk memahami suatu konsep dan menyelesaikan tugas (task), sehingga terbentuk pemahaman dan pengalaman belajar yang lama. Model pembelajaran ini terus mengalami perkembangan mulai dari tingkat Sekolah Dasar hingga sekolah menengah. Proses pembelajaran ini mendidik siswa berinteraksi sosial dengan lingkungan. Prinsip belajar terpadu ini sejalan dengan empat pilar pendidikan yang digariskan UNESCO dalam kegiatan pembelajaran. Empat pilar itu adalah "belajar untuk mengetahui (learning to know), belajar untuk berbuat (learning to do), belajar untuk menjadi diri sendiri (learning to be), dan belajar hidup dalam kebersamaan (Learning to live together) (Widodo, 2009).

Melalui Pembelajaran $C I R C$, diharapkan model pembelajaran tersebut dapat merubah rendahnya kegiatan belajar Bahasa Indonesia siswa kelas X IPS 1 SMA Negeri 9 Kota Jambi tahun pelajaran 2019/2020 menjadi lebih aktif serta meningkatkan prestasi belajar Bahasa Indonesia siswa, karena metode pembelajaran CIRC didesain untuk meningkatkan rasa tanggung jawab siswa terhadap pembelajaranya sendiri dan juga pembelajaran kelompoknya. Siswa tidak hanya mempelajari materi yang diberikan, tetapi mereka juga harus bertanggung jawab terhadap pembelajaran kelompoknya.

\section{METODE PENELITIAN}

Pada penelitian ini digunakan penelitian tindakan kelas (PTK) yang dalam Bahasa Inggris disebut dengan "Classroom Action Research". Penelitian tindakan kelas ini dilaksanakan di SMA Negeri 9 Kota Jambi yang beralamat di jalan Berdikari No.RT.28, Payo Selincah, Paal Merah, Kota Jambi, Jambi 36254. Adapun subjek penelitian ini adalah siswa kelas X IPS 1 SMA Negeri 9 Kota Jambi tahun pelajaran 2019/2020. Penelitian ini dilaksanakan pada semeter 1 tahun ajaran 2019/2020 sebanyak 36 orang terdiri dari 18 siswa laki-laki dan 18 siswa perempuan, dengan waktu efektif selama 6 bulan, dimulai dari bulan Mei-Oktober 2019 .

Adapun alokasi waktu yang digunakan untuk penelitian, Tahapan kegiatannya yaitu: penyusunan proposal penelitian, Observasi, pelaksanaan siklus I, pelaksanaan siklus II, pengolahan data, lalu menyidangkan hasil penelitian. Penelitian tindakan kelas ini dilaksanakan melalui 2 siklus (sesuai kebutuhan) untuk melihat dan memperbaiki pembelajaran Bahasa Indonesia dengan menggunakan metode CIRC.

Prosedur PTK dimulai dengan siklus pertama yang terdiri dari empat prosedur yaitu: (1) perencanaan, (2) pelaksanaan, (3) pengamatan dan (4) refleksi. Setelah siklus pertama dilaksanakan dan mengetahui letak keberhasilan atau hambatanya, peneliti menentukan rencana berikutnya pada siklus kedua, siklus kedua ini merupakan tindak lanjut dari siklus yang pertama. Di siklus kedua ini peneliti bisa memperbaiki tingkat kesulitan atau hambatan dari siklus pertama. Teknik yang akan dilakukan dalam penelitiaan tindakan kelas dalam penelitian ini terdiri dari: Tes, Observasi, dan diskusi teman sejawat.

Dalam Penelitian Tindakan Kelas (PTK) ini yang akan dilihat indikator kinerjanya yaitu proses pembelajaran dengan menggunakan metode CIRC selain siswa dan guru. Analisis dilaksanakan dengan melakukan telaah terhadap fenomena atau peristiwa secara keseluruhan, 
maupun terhadap bagian-bagian yang membentuk fenomena-fenomena tersebut serta hubungan keterkaitanya. Dalam penelitian tindakan kelas (PTK) analisis data dilakukan oleh peneliti semenjak awal, pada setiap aspek penelitian.

\section{HASIL DAN PEMBAHASAN}

Sebelum pelaksanaan penelitian dengan menggunakan metode $C I R C$, rata-rata prestasi belajar Bahasa Indonesia semester I kelas X IPS 1 SMA Negeri 9 Kota Jambi tahun ajaran 2019/2020 menunjukkan angka 66,07. Kondisi tersebut menjadikan indikator pada penelitian ini bahwa kemampuan belajar Bahasa Indonesia siswa masih rendah. Hasil penelitian yang dapat diuraikan adalah data yang didapat mengenai kemampuan siswa dalam pembelajaran Bahasa Indonesia sebelum dilaksanakan tindakan dan setelah dilakukan tindakan. Pelaksanaan penelitian tindakan kelas ini dilaksanakan dalam sebanyak dua siklus.

\section{Aktifitas Belajar Siswa di Siklus I dan Siklus II}

Aktivitas belajar itu sangat diperlukan oleh siswa untuk mendapatkan hasil belajar yang maksimum. Ketika peserta didik pasif, atau hanya menerima dari pengajar, ada kecenderungan untuk cepat melupakan apa yang telah diberikan. Oleh sebab itu, diperlukan perangkat tertentu untuk dapat mengikat informasi yang baru saja diterima dari guru. Dengan adanya aktifitas belajar yang baik maka siswa akan belajar lebih aktif dan pada akhirnya hasil belajar dapat dicapai secara maksimal. Untuk itu keaktifan sangat diperlukan dalam proses pembelajaran.

Aktivitas belajar siswa di siklus I masih belum sesuai harapan, sebagian siswa belum dapat mengikuti pembelajaran dengan menggunakan metode CIRC dengan baik. Siswa terlihat belum terbiasa dengan cara pembelajaran kooperatif seperti CIRC. Masih banyak siswa yang tidak fokus dalam pembelajarannya, keadaan tersebut membuat pembelajaran dengan menggunakan metode CIRC tidak berjalan dengan optimal, Interaksi antar siswa dalam konteks pembelajaran belum terlihat aktif. Guru masih aktif dalam pembelajaran untuk mengarahkan siswa agar dapat mengikuti pembelajaran dengan penerapan metode CIRC. Namun di siklus II, setelah melakukan refleksi guru dapat memfasilitasi pembelajaran siswa sehingga pembelajaran dengan menggunakan metode CIRC dapat berjalan dengan baik. Siswa lebih interaktif dalam pembelaranya, lebih bertanggung jawab pada kelompoknya, proses pembelajaran Bahasa Indonesia yang memiliki konsep penguasaan kemampuan berbicara, membaca, menulis serta berbicara dapat diasah dalam pembelajaran kelompoknya. Berikut perbandingan data yang didapat pada siklus I dan II:

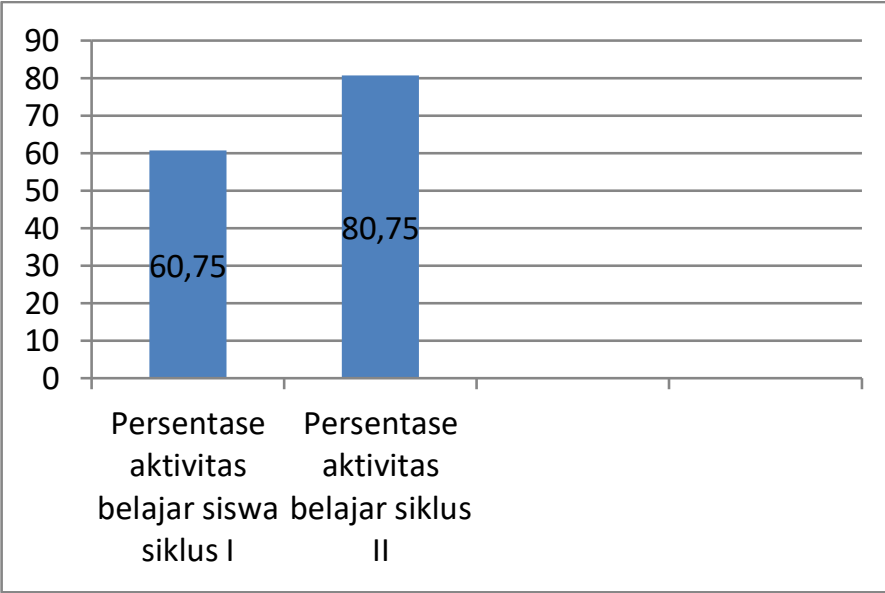

\section{Gambar 1. Persentase Aktivitas Belajar siswa Siklus I dan II}

Dari data tersebut terlihat perubahan yang positif terjadi pada siklus II, persentase aktivitas belajar siswa mengalami kenaikan menjadi $80.75 \%$ yang sebelumnya (di siklus I) hanya mencapai $60.75 \%$. Dengan kata lain, metode CIRC telah dapat meningkatkan aktivitas pembelajaran siswa pada pembelajaran Bahasa Indonesia di SMA Negeri 9 Kota Jambi. 


\section{Hasil Belajar Siswa di Siklus I dan II}

Sama halnya dengan aktivitas belajar, hasil belajar siswa mengalami peningkatan di siklus II. Aktivitas belajar siswa berpengaruh terhadap proses pembelajaran siswa sehingga berdampak untuk hasil belajar yang didapatkan oleh siswa di setiap siklus. Berikut perbandingan hasil belajar siswa siklus I dan II:

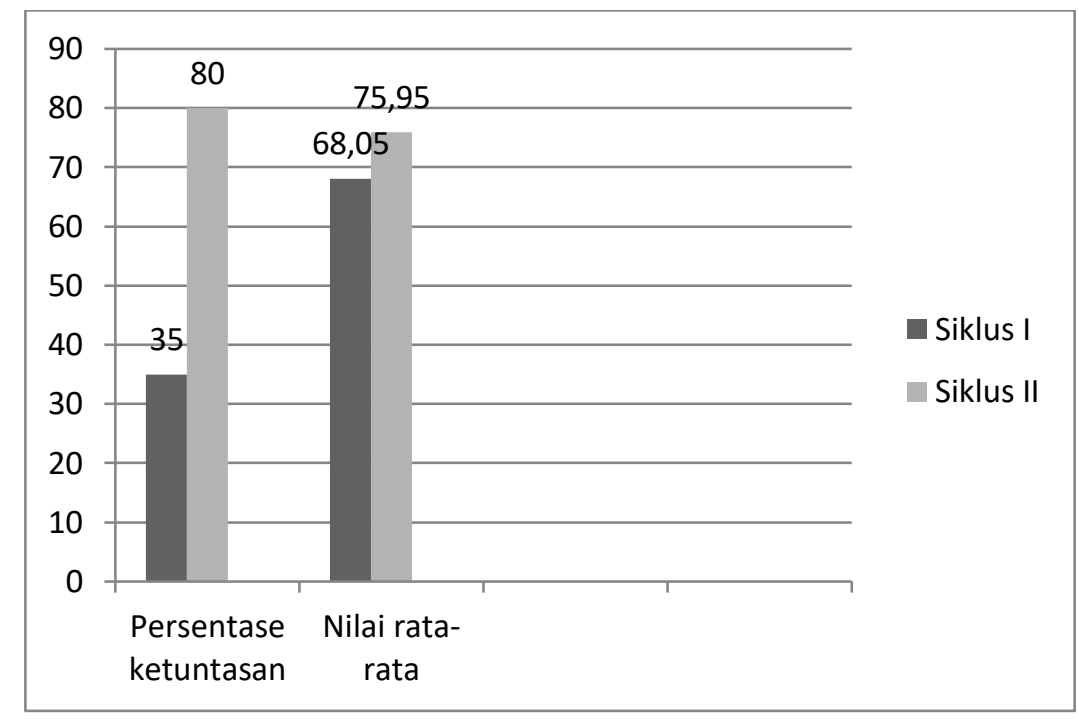

Gambar 2. Grafik Prestasi belajar siswa siklus I dan siklus II

Penelitian pada siklus I, prestasi belajar yang diperoleh oleh siswa masih sangat rendah, masih banyak siswa yang belum mencapai KKM yang sudah ditentukan yaitu 70. Dengan demikian peneliti kembali melakukan penelitian pada siklus II, guna lebih meningkatkan prestasi belajar siswa tentunya dengan memperbaiki masalah yang ada pada siklus I.

Berdasarkan hasil penelitian yang telah dikemukakan di atas, dapat dikatakan bahwa metode CIRC dapat memberikan pengalaman bermakna kepada guru dan siswa, sehingga dapat meningkatkan prestasi belajar Bahasa Indonesia.

Pada siklus I diperoleh nilai rata-rata 68.05 dengan persentase ketuntasan mencapai $35 \%$, berdasarkan hasil tes siklus I, siswa yang mencapai ketuntasan sebanyak 13 orang dengan persentase ketuntasan 35\%, dan siswa yang belum tuntas mencapai 23 orang (65\%).

Data yang diperoleh pada siklus I menunjukan bahwa indikator keberhasilan tindakan belum tercapai. Ini berarti kemampuan siswa dalam menyelesaikan test masih kurang, khususnya dalam pemahaman tentang isi bacaan dalam paragraf. Rendahnya keberhasilan siswa dalam test akhir pada tindakan siklus I disebabkan siswa tidak begitu mengerti penjelasan yang diberikan guru serta rendahnya kerjasama antar siswa dalam kelompok. Oleh karena itu, data yang diperoleh pada siklus I belum mencapai keberhasilan, maka peneliti melakukan siklus II dengan memperbaiki kekurangan di siklus I.

Setelah melakukan beberapa perbaikan penelitian pembelajaran pada siklus II dapat diperoleh nilai tes siswa yaitu hampir semua siswa dari jumlah 36 orang mencapai KKM dan mencapai ketuntasan dalam belajar. Pada tahap siklus II ini peneliti memperoleh data nilai ratarata 75.95 dengan persentase ketuntasan seluruh siswa mencapai $80 \%$. Dengan menggunakan metode $C I R C$ yang menekankan pembelajaran yang tidak monoton dan tidak hanya berpusat pada gurunya saja melainkan pembelajaran yang berpusat pada siswa, dapat meningkatkan hasil belajar siswa. Berdasarkan hasil test akhir pada siklus II ini diketahui bahwa tindakan yang telah dilakukan oleh peneliti sudah mencapai apa yang diharapkan dengan pencapaian nilai rata-rata yang masuk dalam kategori berhasil yaitu 75.95. Dari keterangan di atas dapat disimpulkan bahwa dengan menggunakan metode CIRC dalam pembelajaran Bahasa Indonesia 80\% siswa sudah mencapai KKM dan memperoleh nilai yang memuaskan.

Berdasarkan hasil analisis penelitian tindakan kelas dapat disimpulkan bahwa penerapan metode CIRC dapat meningkatkan prestasi belajar Bahasa Indonesia pada siswa 
kelas X IPS 1 SMA Negeri 9 Kota Jambi tahun ajaran 2019/2020. Dari hasil analisis siklus I diperoleh nilai rata-rata 68.05 dengan persentase ketuntasan mencapai $35 \%$, hal ini menunjukan bahwa siswa belum sepenuhnya mencapai ketuntasan belajar. Pada siklus II, ada peningkatan, untuk siklus II dengan nilai rata-rata 75,95 atau sudah termasuk kriteria sangat baik dengan persentase ketuntasan mencapai $80 \%$ atau sebanyak 29 siswa. Hal ini menunjukan bahwa adanya peningkatan nilai rata-rata dan persentase ketuntasan belajar siswa pada siklus II, karena 2 kriteria ini sudah memenuhi kriteria ketuntasan maka penelitian dicukupkan di siklus II.

Hasil penelitian ini sejalan dengan hasil penelitian yang dilakukan oleh Kurniawan (2012) yang menyatakan bahwa model pembelajaran kooperatif CIRC (Cooperative Integrated Reading and Composition) dapat meningkatkan hasil belajar bahasa indonesia siswa kelas IV SD Negeri Pajang III tahun 2011/ 2012. Dibuktikan dengan hasil belajar siswa yang meningkat dari keadaan prasiklus adalah 44,74\%, pada siklus I menjadi 73,67\%, dan pada siklus II hasil belajar siswa mencapai 94,60\%. Berdasarkan hasil penelitian tersebut maka dapat disimpulkan bahwa melalui penerapan model pembelajaran kooperatif CIRC (Cooperative Integrated Reading and Composition) dapat meningkatkan hasil belajar bahasa indonesia siswa kelas IV SD Negeri Pajang III tahun 2011/ 2012. Diperkuat lagi dengan hasil penelitian dari Chorida (2016) yang menunjukkan hasil yang sama.

Dari penelitian tersebut di atas membuktikan bahwa metode CIRC sangat cocok diterapkan pada materi-materi yang membutuhkan pemahaman bacaan, dilihat dari hasil belajar yang ditingkatkan dengan menggunakan metode CIRC pada penelitian-penelitian tersebut.

\section{KESIMPULAN}

Berdasarkan hasil penelitian yang dilakukan dengan judul "Upaya Peningkatan Prestasi Belajar Bahasa Indonesia Melalui Metode Cooperative Integrated Reading and Composition (CIRC) Untuk Siswa SMAN 9 Kota Jambi" ini, dapat disimpulkan bahwa penerapan metode CIRC dapat meningkatkan prestasi belajar Bahasa Indonesia pada siswa kelas X IPS 1 SMA Negeri 9 Kota Jambi tahun ajaran 2019/2020. Dari hasil analisis siklus I diperoleh nilai ratarata 68.05 dengan persentase ketuntasan mencapai 35\%, hal ini menunjukan bahwa siswa belum sepenuhnya mencapai ketuntasan belajar. Pada siklus II, ada peningkatan, untuk siklus II dengan nilai rata-rata 75,95 atau sudah termasuk kriteria sangat baik dengan persentase ketuntasan mencapai $80 \%$. Hal ini menunjukan bahwa adanya peningkatan nilai rata-rata dan persentase ketuntasan belajar siswa pada siklus II, karena 2 kriteria ini sudah memenuhi kriteria ketuntasan maka penelitian dicukupkan di siklus II.

\section{DAFTAR PUSTAKA}

Ekawati, R., Susetyarini, E., Pantiwati, Y., \& Husamah, H. (2015). Peningkatan hasil belajar dan kemampuan berpikir kritis dengan model pembelajaran cooperative integrated reading and composition (CIRC). JPBI (Jurnal Pendidikan Biologi Indonesia), 1(3).

Fitriyani, Y., Gunawan, A., \& Lestari, M. A. (2020). Efektivitas Pembelajaran Cooperative Script, Artikulasi dan Cooperative Integrated Reading and Composition terhadap Pemahaman Konsep Siswa Sekolah Dasar. Profesi Pendidikan Dasar, 7(2), 129-139.

Huda, Miftahul (2015). Cooperative Learning. Yogyakarta: Pustaka Pelajar.

Inayah, R. (2013). Pengaruh kompetensi guru, motivasi belajar siswa, dan fasilitas belajar terhadap prestasi belajar mata pelajaran ekonomi pada siswa kelas XI IPS SMA Negeri 1 Lasem Jawa Tengah Tahun Pelajaran 2011/2012. S2 Pendidikan Ekonomi, 2(1).

Muthoharoh, N. B. (2017). Pengaruh Model Pembelajaran Kooperatif" Think Pair Share" terhadap Hasil Belajar Bahasa Inggris. SAP (Susunan Artikel Pendidikan), 2(1).

Nai, F. A. (2017). Teori belajar dan pembelajaran implementasinya dalam pembelajaran bahasa Indonesia di SMP, SMA, dan SMK. Deepublish.

Nurjaya, G. (2012). Pengembangan bahan ajar metode pembelajaran bahasa dan sastra Indonesia berbasis pembelajaran kooperatif Jigsaw untuk meningkatkan pemahaman dan kemampuan aplikatif mahasiswa. JPI (Jurnal Pendidikan Indonesia), 1(2). 
Nur Asiah. (2014). Inovasi Pembelajaran Suatu Pendekatan Teori Mendesain Pembelajaran. PT. Anugrah Utama Raharja. Bandar Lampung

Sari, N. T. I., \& Maimunah, S. (2017). Pengaruh Metode Pembelajaran Kooperatif Tipe Round Robin Terhadap Prestasi Mata Pelajaran Bahasa Indonesia Siswa SMA. Jurnal Ecopsy, 4(1), 25-32.

Susanto, A. D. (2016). STAD: Strategi Meningkatkan Nilai Ujian Nasional Bahasa Indonesia Peserta Didik Kelas Xii Ak 2 Smkn 1 Banyumas Semester Genap 2014/2015. Khazanah Pendidikan, 10(1).

Wardani, K. D. K. A., \& Artawan, G. (2013). Sikap Bahasa Siswa Terhadap Bahasa Indonesia: Studi Kasus di SMA Negeri 1 Singaraja. Jurnal Pendidikan dan Pembelajaran Bahasa Indonesia, 2.

Widodo, R. (2009). Model Pembelajaran Cooperative Integrated Reading and Composition. Unpublished thesis. Semarang: state university of Semarang. 